Wittig, T. W., N. L. Cagle, N. Ocampo-Peñuela, R. Scott Winton, E. Zambello, and Z. Lichtneger. 2017. Species traits and local abundance affect bird-window collision frequency. Avian Conservation and Ecology 12(1):17. https://doi.org/10.5751/ACE-01014-120117

Copyright (C) 2017 by the author(s). Published here under license by the Resilience Alliance.

Research Paper

\title{
Species traits and local abundance affect bird-window collision frequency
}

\author{
Thomas W. Wittig ${ }^{1}$, Nicolette L. Cagle ${ }^{1}$, Natalia Ocampo-Peñuela ${ }^{1,2}$, R Scott Winton ${ }^{1,2}$, Erika Zambello ${ }^{1,3}$ and Zane Lichtneger ${ }^{4}$ \\ ${ }^{1}$ Nicholas School of the Environment, Duke University, Durham, North Carolina, USA, ${ }^{2}$ Department of Environmental System \\ Science, Ecosystem Management, ETH Zürich, Switzerland, ${ }^{3}$ Choctawhatchee Basin Alliance, Santa Rosa Beach, Florida, USA, \\ ${ }^{4}$ SAS Institute Inc., Environmental Program, Cary, North Carolina, USA
}

\begin{abstract}
Studies on bird-window collisions have generally drawn inferences about species' differential vulnerability from collision tallies. However, this common methodology is potentially biased because the number of collisions may simply reflect prevalence of species at the study site rather than species-specific vulnerability. Building on recent studies of abundance and collision rates, we offered a complementary methodology based on point count data that could be widely applied alongside carcass surveys. Additionally, we broadened our analysis beyond previously applied taxonomic and migratory classifications to include functional classifications of feeding guild, breeding status, and synanthropy. Our null hypothesis was that collision frequencies reflect a species' or classification group's prevalence at study sites. To test this possibility, we used collision data collected at three sites in the Research Triangle Area of North Carolina, United States. At one of these sites, Duke University's Main Campus, we also gathered relative abundances from the local bird community to develop a case study assessment of how background prevalence compared to number of collisions. Using the larger, three-site dataset, we developed an initial picture of collision susceptibility based solely on frequency, the standard practice. Then, by bootstrapping our Duke abundance data, we generated confidence intervals that simulated collision based on chance versus prevalence. We identified several instances where collision tallies produced misleading perception of species-specific vulnerability. In the most extreme case, frequencies from our Triangle Area dataset indicated locally breeding species were highly vulnerable to collisions while our abundance-based case study suggested this same group was actually adept at avoiding collisions. Through our case study, we also found that foliage gleaning was linked to increased risk, and omnivory and ground foraging were associated with decreased risk. Although our results are based on a limited sample, we argue that abundance needs to be incorporated into future studies and recommend point counts as a noninvasive and adaptable alternative to area-searches and mist netting.
\end{abstract}

\section{Traits spécifiques à l'espèce et abondance affectent la fréquence des collisions d'oiseaux aux fenêtres}

RÉSUMÉ. Les études sur les collisions d'oiseaux aux fenêtres infèrent généralement la vulnérabilité d'une espèce à partir des décomptes de collisions. Toutefois, cette méthodologie fréquemment utilisée est potentiellement biaisée parce que le nombre de collision reflète simplement la prévalence de certaines espèces au site d'étude plutôt que la vulnérabilité réelle de l'espèce. À partir des récentes études d'abondance et de taux de collision, nous offrons une méthodologie complémentaire basée sur des recensements ponctuels qui pourrait être appliquée à large échelle en parallèle avec les décomptes de carcasses. De plus, nous avons élargit nos analyses au-delà des classifications taxonomiques et migratoires utilisées auparavant, afin d'inclure les classifications fonctionnelles de guilde alimentaire, statut de reproduction, et le facteur de synanthropie. Notre hypothèse nulle est que la fréquence des collisions reflète une prévalence d'une espèce ou d'un groupe de même classe au site d'étude. Afin de tester cette possibilité, nous avons utilisé les données de collision collectées sur trois sites dans la Zone Triangle de Recherche en Caroline du Nord, aux États-Unis. Sur l'un des sites, le Campus Principal de l'Université de Duke, nous avons aussi amassé les abondances relatives de la communauté locale aviaire, afin de développer une étude de cas sur la comparaison de la prévalence en arrière-plan et le nombre de collision. Utilisant la banque de donnée des trois sites, plus vaste, nous avons développé une image initiale de susceptibilité de collision basée seulement sur la fréquence, la méthode courante. Ensuite, en utilisant le bootstrap sur nos données d'abondance de Duke, nous avons généré des intervalles de confiance simulant les collisions basées par chance comparé à la prévalence. Nous avons identifié plusieurs instances où les totaux de collisions ont produit une fausse perception de vulnérabilité spécifique due à l'espèce. Dans les cas les plus extrêmes, nos données de la Zone Triangle indiquèrent que les espèces se reproduisant localement étaient grandement vulnérable aux collisions, alors que notre étude de cas basée sur l'abondance suggérait que ce même groupe était adepte à éviter les collisions. À partir de notre étude de cas, nous avons aussi découvert que les glaneurs de feuillage étaient liés à un risque plus élevé, alors que l'omnivorisme et l'alimentation au sol étaient associés à une diminution du risque. Malgré que nos résultats soient basés sur un échantillon limité, nous avançons que l'abondance devrait être incluse dans les études futures et recommandons l'utilisation de recensements ponctuels comme alternative adaptable et non-invasive au-lieu de d'aires de décomptes ou de filets japonais.

Key Words: carcass survey; classifications; collision vulnerability; local abundance; point count; window strikes 


\section{INTRODUCTION}

Window collisions are the second largest source of human-caused avian mortality in North America (Loss et al. 2015), killing an estimated one billion birds annually (Loss et al. 2014). Window hazards potentially reduce the North American bird population by 2 to $9 \%$ (Loss et al. 2014), and could have cascading effects on ecosystems and the goods and services they provide (Longcore and Smith 2013).

Since the foundational work of Klem in the late 1970s (Klem 1989, Klem 1990a,b), researchers have begun asking a wide range of questions about this phenomenon: What building qualities increase collision risk? Are habitat conditions surrounding buildings relevant? How do collision frequencies vary across seasons? One question continues to trouble researchers and remains largely unresolved: Which birds are most susceptible?

An improved understanding of susceptibility would have significant implications for both collision mitigation and broader conservation efforts. It could inform collision deterrent methods and facilitate the integration of window collision threats into bird conservation frameworks. Collision mortality may have additive effects on species that are already suffering from habitat loss and degradation (Klem 2009, 2010). Failing to recognize compounding relationships among threats may harm species' long-term survival.

To properly address which groups of birds are most susceptible to collisions with windows, researchers must first deal with the confounding effect of local abundance. It is clear that collision frequencies are at least partly attributable to background prevalence (Kahle et al. 2016, Sabo et al. 2016). This attribute has the power to inflate collision frequencies among locally abundant birds and suppress frequencies among scarcer species, independent of the degree of inherent susceptibility among these various groups. Many studies have found it difficult to account for abundance when characterizing species-specific susceptibility or have entirely neglected its influence. Of those studies that have acknowledged this issue, some have offered anecdotal evidence of relationships between local abundance and collision (Blem and Willis et al. 1998, O'Connell et al. 2001) and others have systematically observed bird communities near study sites, but in limited spatial or seasonal contexts (Dunn 1993, Hager et al. 2008).

Some of the geographically broader investigations of abundance and vulnerability have come from Arnold and Zink (2011) and Loss et al. (2014). In these studies, the authors gathered collision rates from other investigations and compared these values with population estimates from the North American Breeding Bird Survey to index the relative vulnerability of species. Although broadly informative, this approach assumes similarity of local study site communities and regional scale populations and introduces the possibility of spurious correlations because of pseudocorrelation with variables related to those upon which data was not actually collected (see Schaub et al. 2011 for examples).

To date, only a handful of studies have attempted to explore the association between local abundance and collisions. Kahle et al. (2016) collected collision data at a museum building in California and conducted area search surveys adjacent to the museum multiple times per week for a year to establish an understanding of local avifauna abundance. Although their results offered valuable insight into the relationship between abundance and collision, the study's West Coast location means the findings are difficult to relate to the majority of collision literature, which is based in the eastern United States. Migratory bird behavior is very different in eastern North America along the Mississippi and Atlantic flyways, compared to migration in the western half of the continent. Sabo et al. (2016) produced a similar study at a zoo in Virginia, using mist nets to survey local abundance. These studies represent a major advancement in methodology for birdwindow collision surveys. Yet, these studies have only considered collision susceptibility in terms of demographics (e.g., age, sex), taxonomy, and migratory status.

In this study, we expand the general knowledge of collision vulnerability to inform future mitigation and conservation efforts. We begin by (1) investigating patterns of taxonomy, residency and breeding status, guild, and synanthropy on bird-window collision rates at three sites in North Carolina's Research Triangle region, hereafter referred to as the Triangle Study. In the Triangle Study, we replicate the standard research practice of carcass surveys. We complement this effort by (2) testing whether collision patterns are the product of differential susceptibilities among taxonomic and functional groups, or the product of random chance and relative abundance, using a one-year case study of point counts and collisions at Duke University, hereafter referred to as the Duke Case Study.

We seek to test the following specific hypotheses about bird susceptibility to window-collisions: (1) Resident birds are less susceptible to collisions than migratory species because they have familiarity with windows in their local environment; (2) Synanthropic birds have low susceptibility to window collisions either as an adaptation to survive in human-dominated landscapes or because innate resistance to window-collisions allowed them to become synanthropic; (3) Birds in foliagegleaning foraging guilds will be more susceptible than others because reflected foliage represents a potential food source and is a strong attractant.

\section{METHODS}

\section{Study areas}

We conducted our Triangle Study at three locations in the RaleighDurham-Chapel Hill area of North Carolina, United States (Fig. 1A). At each site, we chose buildings with a wide range of stories, glass coverage, age, and floor area (Ocampo-Peñuela et al. 2016). We selected six buildings per site.

\section{Carcass surveys}

We conducted carcass surveys for the Triangle Study during 21 days of the peak migration period in fall 2015 (19 September-9 October), following methods described by Hager and Consentino (2014). One day prior to this period (18 September), we conducted a clean-up survey to free the study area of lingering carcasses that would otherwise bias our results. Each day during the subsequent 21-day survey period, two observers independently looked for dead and stunned birds within $2 \mathrm{~m}$ of each building. These observers removed carcasses and recorded collisions to species level when the carcass allowed for visual identification, as well as building name and side (compass direction, i.e., N, S, E, W). We conducted the surveys in the afternoon, as recommended by Hager et al. 2012 to reduce impacts of scavengers on the dataset. 
Fig. 1. (A) Sites for bird window collision study in the Triangle region of North Carolina, (B) Duke University study site with sampled buildings highlighted, (C) 1-m resolution EPA land cover (US EPA 2013), (D) survey points over aerial imagery.

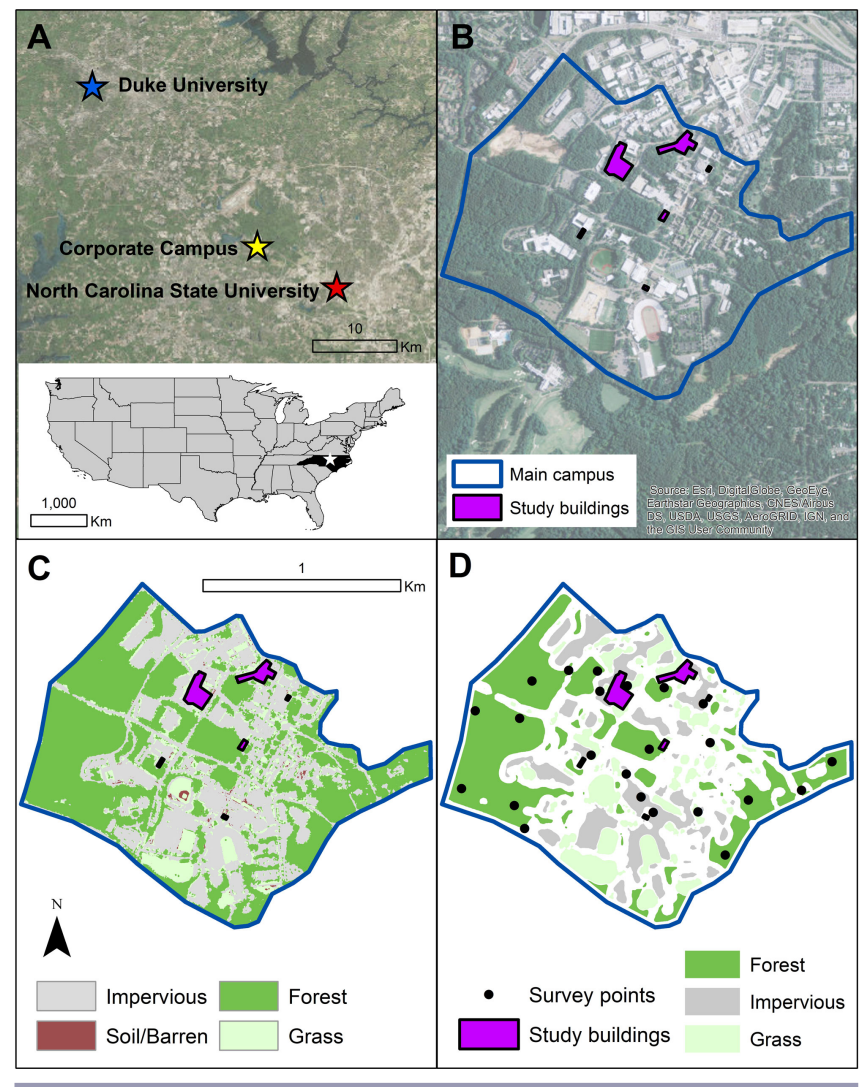

We also conducted an additional carcass survey at Duke University in spring 2015, cleaning on 31 March 2015, and surveying from 1 to 21 April following the same methodology (Hager and Consentino 2014). We only used this data in the Duke Case Study. (See Ocampo-Peñuela et al. 2016 for further details of carcass surveys at Duke University, including methodology and campus description.)

If observers were unable to identify what species collided, we excluded the observation from our analysis. Scavenging often reduces carcasses to an unidentifiable state such as a pile of feathers or partial remains. Our surveys were timed to limit the impact of scavenging. Nonetheless, unidentified collisions accounted for $20 \%$ and $14 \%$ of total collisions in the Triangle Study and Duke Case Study, respectively.

\section{Further classifications}

To investigate the potential influences of taxonomy, behavior, and life history on bird species susceptibility to window collisions, we classified species based on taxonomic family, breeding and migration status, feeding guild and location, and synanthropy.

We defined breeding status as whether or not the species had been recorded breeding locally (within the Triangle area, including Durham, Orange, Wake, and Chatham Counties) by expert local observers from the Chapel Hill Bird Club (Cook 2008, LeGrande et al. 2016). By using the term "locally breeding," we did not mean to indicate individual birds were observed actively breeding in the study area; our methods did not include the mark and recapture, territory mapping, or telemetry necessary to glean this detail. Rather, we applied this term to identify a behavior exhibited by at least some members of a given species within our study region. Migration status (binary variable: migratory, year round) was determined from seasonal, local fluctuations in abundance reported by Cook (2008). Birds that were not reported or were only very rarely reported in some seasons, but were common or abundant in other seasons, were considered migratory. As with breeding status, this term does not reflect knowledge of individual birds, but a broader categorization of species behavior in the Triangle area.

We defined feeding guilds based on González-Salazar et al.'s (2014) classification. Broad guilds (e.g., insectivore, granivore) were then subdivided by feeding strategy, feeding location, and height.

For synanthropy, the degree of positive association with human environments, we applied Johnston's (2001) classification of North American avifauna. Under this classification, bird species were defined as full synanthropes, casual synanthropes, tangential synanthropes, or nonsynanthropes. Synanthropy "includes a wide degree of relationship to humans" from dependence on human ecology for survival (full), exploitation without dependence (causal), occasional exploitation (tangential), to no positive synanthropic relationship (nonsynanthropes; Johnston 2001:50).

\section{Duke case study: point count survey}

We complemented our spring and fall carcass surveys at Duke with relative abundance data gathered from point counts around Main Campus (Fig. 1B). To assign survey point locations, we used a stratified random sampling technique, applied in ArcMap 10.3.1 (ESRI 2015). Beginning with 1-m resolution EPA land cover classification (US EPA 2013), we used a focal calculation to remove irrelevant features such as trees in parking lots. Duke's Main Campus contained four classes: forest, impervious, grass, and bare earth (Fig. 1C). The last two classes were combined because of the negligible area of the latter. We limited the sampling frame for forest and impervious classes to locations with at least $85 \%$ coverage in a $25-\mathrm{m}$ radius and $30 \%$ for the much scarcer grass class. To avoid surveying habitat outside the purview of Duke, we removed areas $25 \mathrm{~m}$ from the Main Campus boundary from sampling consideration.

We then randomly placed 21 points to the remaining areas, with the number of points assigned to each class roughly proportional to their relative area and separated by at least $90 \mathrm{~m}$ to improve independence of observations. The result was 12 forest, 5 impervious, and 4 grass points (Fig. 2D).

A single observer (TW) conducted point counts during the same peak migration survey periods as the spring and fall 2015 Duke University carcass surveys. TW visited every point three times during both survey seasons, altering the order of visitation to avoid bias. At survey locations, we reported all birds seen or heard within a 25-m-fixed radius, not counting flyovers (Bibby et al. 2000). We attempted to avoid counting individuals more than once per visit by maintaining awareness of individual positioning 
and using a short, 10-minute period of observation. Additionally, we completed surveys within 2.5 hours of sunrise to take advantage of higher activity and detectability of birds. We did not conduct surveys during strong winds or precipitation.

Construction and maintenance projects at Duke required two alterations to our original survey design. In spring 2015, Duke University converted approximately 2 ha of forest cover to a water reclamation pond. We incorporated this water feature and maintained our ratio of points to cover area by relocating a nearby forest survey point to the pond shore and reclassifying it as water. Additionally, between spring 2015 and fall 2015, two survey points became inaccessible because of construction. We compensated for this loss by randomly assigning two new survey points for fall 2015 using the same sampling technique. These new points were similar to the original points in vegetation composition and structure, as well as degree of development, justifying comparison across seasons.

\section{Duke case study: analysis of bird-window collision abundance and susceptibility}

To test if species' local abundance has an effect on number of collisions at Duke University, we compared the observed rate of collision in each classification category (e.g., Parulidae, casual synanthrope, granivore) to a simulated rate for those categories based on chance and background occurrence rates. This analysis drew on the point count data from spring and fall 2015 and the Duke carcass data from those same periods. Our comparison of random collision used 95\% confidence intervals (CIs) based on distributions of random sampling rates for each bird category in our point count dataset.

We constructed these random distributions by applying a bootstrapping sampling procedure to the Duke Main Campus abundance data in R, v. 3.2.2 (R Development Core Team 2015). Pulling from a pool of all spring and fall point count observations, we sampled a number of individuals equal to the number of collisions observed at Duke during the 2015 spring and fall carcass surveys. Each individual in the sample pool had an equal probability of being selected, simulating collision in the absence of differential vulnerability.

We repeated the sampling 10,000 times and recorded the proportion of birds sampled from each category after every run. These 10,000 runs created a frequency distribution of random sampling rates for each avian category based solely on their campus abundance. We identified our $95 \%$ CIs by pulling out the 275 th and 9750 th values from the ordered vector of sampling rates for each bird category. We repeated this procedure on all classification approaches (e.g., foraging location guild, family, synanthropy).

We then compared these intervals to the observed rate of collision among different bird groups. To calculate the observed rates, we divided the collision frequency in each class by the total number of collisions. Placing these values alongside the CIs, we noted whether a class fell below, within, or above the expected rate of collision. We deemed species with values above the simulated rates as disproportionately susceptible to collisions and species with values below as less susceptible to collisions.

\section{RESULTS}

\section{Triangle Study frequencies}

Between 18 September and 9 October 2015, we recorded 151 birds colliding with survey buildings at our three study sites in the Research Triangle Area (Table 1). Among these 138 casualties (the remaining 13 casualties were not visually identifiable), we observed 40 species, 14 families, and 4 orders. The vast majority of collisions were Passeriformes ( $81 \%$ ), and the remaining causalities were nonpasserine orders.

\section{Taxonomy}

The Parulidae, Turdidae, and Trochilidae families accounted for approximately two-thirds of all collisions (Fig. 2A). The Parulidae had more collisions than Turdidae and Trochilidae combined. Although the Parulidae collisions represented a wide diversity of species (15), the Trochilidae consisted of only one, the Ruby-throated Hummingbird (Archilochus colubris).

\section{Breeding and migration status}

Collision frequencies indicated local breeders collided roughly twice as much as nonlocal breeders (Fig. 2B). Birds that migrate (i.e., nonyear-round residents) showed an even greater disparity between its two classes (Fig. 2C). There was an approximately 14:1 ratio of casualties of species known to migrate compared to year round residents.

\section{Feeding guild}

Insectivores collided far more than any other feeding group (Fig. 2D). Nectarivores were also well represented in the collision tally, but as with the Trochilidae results, this finding was solely attributable to Ruby-throated Hummingbirds. Of the 114 insectivore collisions, 94 belonged to just 3 subgroups: lower canopy foliage gleaners, ground gleaners, and upper canopy foliage gleaners (Fig. 2E).

\section{Synanthropy}

Collisions were nearly evenly split between nonsynanthropes and tangential synanthropes (Fig. 2F). Conversely, the more synanthropic classes (casual and full) had very few collisions.

\section{Duke case study: local abundance and collision susceptibility}

During carcass surveys at Duke University in spring and fall 2015, we documented 36 birds, representing 19 species and 11 families. The majority $(72 \%)$ of individual casualties classified as migratory species, $58 \%$ were insectivores $(22 \%$ of which were lower canopy gleaners), and the majority of birds $(89 \%)$ were tangential synanthropes or nonsynanthropic.

During the point count surveys, we recorded 477 birds representing 40 species and 21 families (Table 2). The five most frequently observed species were, in decreasing order, Northern Cardinal (Cardinalis cardinalis, 60 individuals), House Finch (Haemorhous mexicanus, 51 individuals), Eastern Towhee (Pipilo erythrophthalmus, 37 individuals), Northern Mockingbird (Mimus polyglottos, 35 individuals), and Carolina Chickadee (Poecile carolinensis, 35 individuals). The top 10 most abundant species accounted for $69 \%$ of observations. We observed 17 of the 40 species fewer than four times. These rarer birds included four Parulidae, two Picidae, and two Sittidae species. 
Avian Conservation and Ecology 12(1): 17

http://www.ace-eco.org/vol12/iss1/art17/

Table 1. Taxonomic classification, guild, feeding location, synanthropy (SY), local breeding status (LB), and migration status (MG) of birds that collided with windows on the three Triangle campuses from September 18 until October 9, 2015.

\begin{tabular}{|c|c|c|c|c|c|c|c|c|}
\hline Common Name & Scientific Name & Family & $\begin{array}{c}\text { Total \# } \\
\text { Birds } \\
\end{array}$ & Guild $^{\dagger}$ & Location $^{\dagger}$ & Local Breeders & Migrants $^{8}$ & Synanthropy \\
\hline $\begin{array}{l}\text { Ruby-throated } \\
\text { Hummingbird }\end{array}$ & Archilochus colubris & Trochilidae & 16 & nectarivore & nectarivore & $\mathrm{L}$ & M & $\mathrm{T}$ \\
\hline Common Yellowthroat & Geothlypis trichas & Parulidae & 9 & insectivore & $\begin{array}{c}\text { lower canopy foliage } \\
\text { gleaner }\end{array}$ & $\mathrm{L}$ & M & $\mathrm{T}$ \\
\hline Northern Parula & Setophaga americana & Parulidae & 9 & insectivore & $\begin{array}{l}\text { upper canopy foliage } \\
\text { gleaner }\end{array}$ & $\mathrm{L}$ & M & $\mathrm{X}$ \\
\hline Red-eyed Vireo & Vireo olivaceus & Vireonidae & 9 & insectivore & $\begin{array}{c}\text { lower canopy foliage } \\
\text { gleaner }\end{array}$ & $\mathrm{L}$ & M & $\mathrm{T}$ \\
\hline Swainson's Thrush & Catharus ustulatus & Turdidae & 8 & insectivore & $\begin{array}{c}\text { lower canopy foliage } \\
\text { gleaner }\end{array}$ & & M & $\mathrm{T}$ \\
\hline $\begin{array}{l}\text { Yellow-bellied } \\
\text { Sapsucker }\end{array}$ & Sphyrapicus varius & Picidae & 7 & insectivore & bark excavator & & M & $\mathrm{X}$ \\
\hline $\begin{array}{l}\text { Black-throated Blue } \\
\text { Warbler }\end{array}$ & Setophaga caerulescens & Parulidae & 6 & insectivore & $\begin{array}{l}\text { lower canopy foliage } \\
\text { gleaner }\end{array}$ & & M & $\mathrm{X}$ \\
\hline Gray-cheeked Thrush & Catharus minimus & Turdidae & 6 & insectivore & ground gleaner & & M & $\mathrm{X}$ \\
\hline American Redstart & Setophaga ruticilla & Parulidae & 5 & insectivore & $\begin{array}{l}\text { air hawker under } \\
\text { canopy }\end{array}$ & $\mathrm{L}$ & M & $\mathrm{T}$ \\
\hline Wood Thrush & Hylocichla mustelina & Turdidae & 5 & insectivore & ground gleaner & $\mathrm{L}$ & M & $\mathrm{X}$ \\
\hline Chestnut-sided Warbler & Setophaga pensylvanica & Parulidae & 4 & insectivore & $\begin{array}{c}\text { lower canopy foliage } \\
\text { gleaner }\end{array}$ & & M & $\mathrm{X}$ \\
\hline Gray Catbird & Dumetella carolinensis & Mimidae & 4 & insectivore & ground gleaner & $\mathrm{L}$ & M & $\mathrm{T}$ \\
\hline Pine Warbler & Setophaga pinus & Parulidae & 4 & insectivore & bark gleaner & $\mathrm{L}$ & M & $\mathrm{X}$ \\
\hline American Robin & Turdus migratorius & Turdidae & 3 & insectivore & ground gleaner & $\mathrm{L}$ & M & $\mathrm{C}$ \\
\hline $\begin{array}{l}\text { Black-and-white } \\
\text { Warbler }\end{array}$ & Mniotilta varia & Parulidae & 3 & insectivore & bark gleaner & $\mathrm{L}$ & M & $\mathrm{X}$ \\
\hline Brown Thrasher & Toxostoma rufum & Mimidae & 3 & insectivore & ground gleaner & $\mathrm{L}$ & M & $\mathrm{X}$ \\
\hline Cape May Warbler & Setophaga tigrina & Parulidae & 3 & insectivore & $\begin{array}{l}\text { lower canopy foliage } \\
\text { gleaner }\end{array}$ & & M & $\mathrm{X}$ \\
\hline Mourning Dove & Zenaida macroura & Columbidae & 3 & granivore & $\begin{array}{l}\text { ground to undergrowth } \\
\text { gleaner }\end{array}$ & $\mathrm{L}$ & & $\mathrm{T}$ \\
\hline Ovenbird & Seiurus aurocapilla & Parulidae & 3 & insectivore & ground gleaner & $\mathrm{L}$ & M & $\mathrm{X}$ \\
\hline Summer Tanager & Piranga rubra & Cardinalidae & 3 & insectivore & $\begin{array}{l}\text { upper canopy foliage } \\
\text { gleaner }\end{array}$ & $\mathrm{L}$ & M & $\mathrm{X}$ \\
\hline $\begin{array}{l}\text { Black-throated Green } \\
\text { Warbler }\end{array}$ & Setophaga virens & Parulidae & 2 & insectivore & $\begin{array}{l}\text { lower canopy foliage } \\
\text { gleaner }\end{array}$ & & M & $\mathrm{X}$ \\
\hline Carolina Chickadee & Poecile carolinensis & Paridae & 2 & insectivore & $\begin{array}{l}\text { lower canopy foliage } \\
\text { gleaner }\end{array}$ & $\mathrm{L}$ & & $\mathrm{T}$ \\
\hline Philadelphia Vireo & Vireo philadelphicus & Vireonidae & 2 & insectivore & $\begin{array}{l}\text { lower canopy foliage } \\
\text { gleaner }\end{array}$ & & M & $\mathrm{X}$ \\
\hline Rose-breasted Grosbeak & Pheucticus ludovicianus & Cardinalidae & 2 & insectivore & $\begin{array}{l}\text { upper canopy foliage } \\
\text { gleaner }\end{array}$ & & M & $\mathrm{X}$ \\
\hline Scarlet Tanager & Piranga olivacea & Cardinalidae & 2 & insectivore & $\begin{array}{l}\text { upper canopy foliage } \\
\text { gleaner }\end{array}$ & $\mathrm{L}$ & M & $\mathrm{X}$ \\
\hline American Goldfinch & Spinus tristis & Fringillidae & 1 & granivore & $\begin{array}{c}\text { lower to upper canopy } \\
\text { gleaner }\end{array}$ & $\mathrm{L}$ & M & $\mathrm{T}$ \\
\hline Blue Jay & Cyanocitta cristata & Corvidae & 1 & omnivore & ground forager & $\mathrm{L}$ & M & $\mathrm{T}$ \\
\hline $\begin{array}{l}\text { Brown-headed } \\
\text { Nuthatch }\end{array}$ & Sitta pusilla & Sittidae & 1 & insectivore & bark gleaner & $\mathrm{L}$ & & $\mathrm{X}$ \\
\hline Canada Warbler & Cardellina canadensis & Parulidae & 1 & insectivore & $\begin{array}{l}\text { lower canopy foliage } \\
\text { gleaner }\end{array}$ & & M & $\mathrm{X}$ \\
\hline $\begin{array}{l}\text { Golden-crowned } \\
\text { Kinglet }\end{array}$ & Regulus satrapa & Regulidae & 1 & insectivore & $\begin{array}{l}\text { lower canopy foliage } \\
\text { gleaner }\end{array}$ & & M & $\mathrm{X}$ \\
\hline Indigo Bunting & Passerina cyanea & Cardinalidae & 1 & granivore & $\begin{array}{l}\text { ground to undergrowth } \\
\text { gleaner }\end{array}$ & $\mathrm{L}$ & M & $\mathrm{X}$ \\
\hline Lincoln's Sparrow & Melospiza lincolnii & Emberizidae & 1 & granivore & $\begin{array}{l}\text { ground to undergrowth } \\
\text { gleaner }\end{array}$ & & M & $\mathrm{T}$ \\
\hline Magnolia Warbler & Setophaga magnolia & Parulidae & 1 & insectivore & $\begin{array}{l}\text { lower canopy foliage } \\
\text { gleaner }\end{array}$ & & M & $\mathrm{X}$ \\
\hline Northern Cardinal & Cardinalis cardinalis & Cardinalidae & 1 & granivore & $\begin{array}{l}\text { ground to undergrowth } \\
\text { gleaner }\end{array}$ & $\mathrm{L}$ & & $\mathrm{T}$ \\
\hline Northern Mockingbird & Mimus polyglottos & Mimidae & 1 & insectivore & ground gleaner & $\mathrm{L}$ & & $\mathrm{T}$ \\
\hline Palm Warbler & Setophaga palmarum & Parulidae & 1 & insectivore & ground gleaner & & $\mathrm{M}$ & $\mathrm{X}$ \\
\hline Ruby-crowned Kinglet & Regulus calendula & Regulidae & 1 & insectivore & $\begin{array}{l}\text { lower canopy foliage } \\
\text { gleaner }\end{array}$ & & M & $\mathrm{T}$ \\
\hline Tufted Titmouse & Baeolophus bicolor & Paridae & 1 & insectivore & $\begin{array}{c}\text { lower canopy foliage } \\
\text { gleaner }\end{array}$ & $\mathrm{L}$ & & $\mathrm{T}$ \\
\hline Worm-eating Warbler & Helmitheros vermivorum & Parulidae & 1 & insectivore & $\begin{array}{l}\text { lower canopy foliage } \\
\text { gleaner }\end{array}$ & & M & $\mathrm{X}$ \\
\hline Yellow Warbler & Setophaga petechia & Parulidae & 1 & insectivore & $\begin{array}{l}\text { lower canopy foliage } \\
\text { gleaner }\end{array}$ & & M & $\mathrm{T}$ \\
\hline
\end{tabular}


Avian Conservation and Ecology 12(1): 17

http://www.ace-eco.org/vol12/iss1/art17/

Table 2. Total observations of each species from point counts during spring and fall 2015 at Duke University.

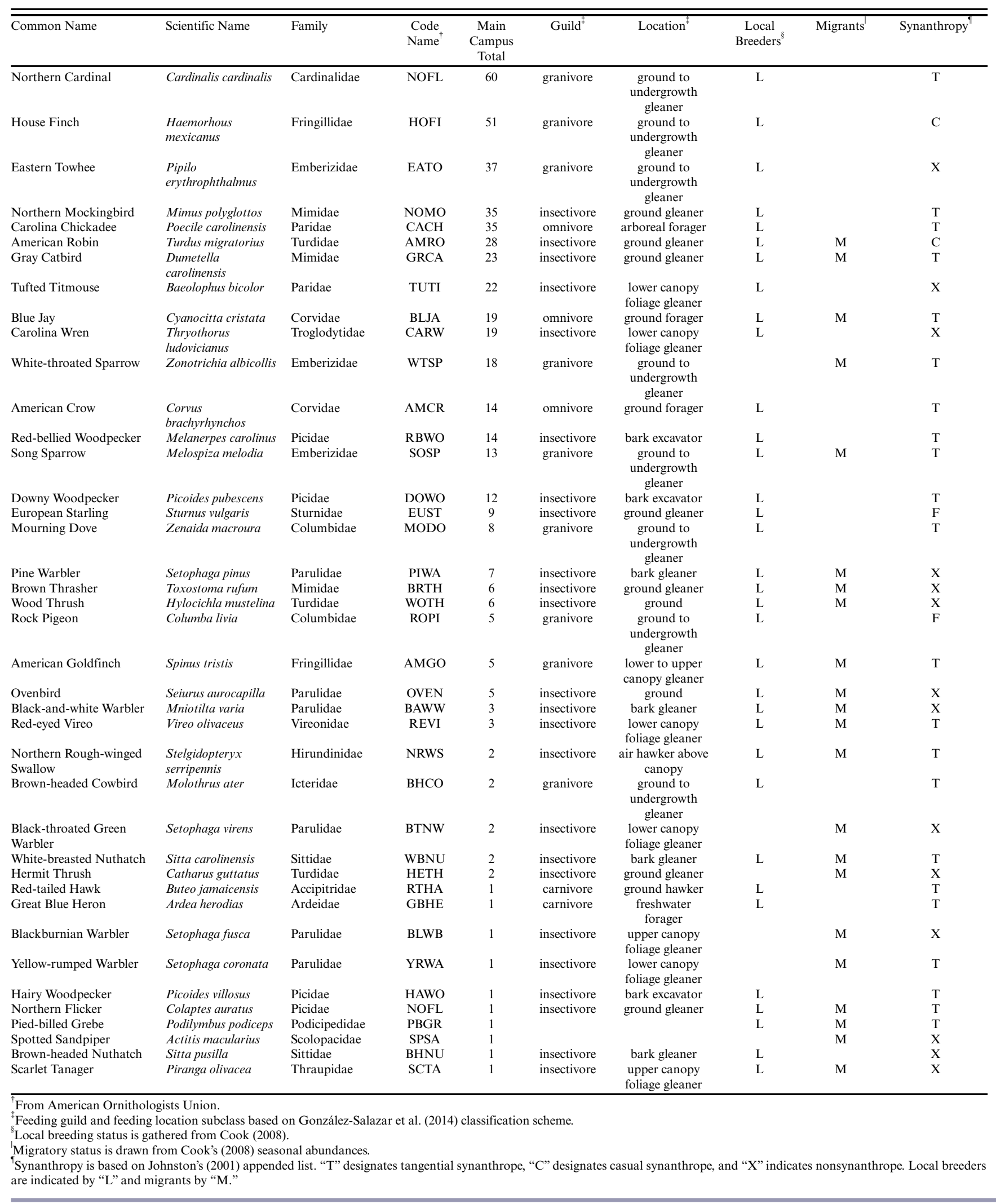


Fig. 2. Frequency of collision victims by (A) family, (B) breeding status, (C) migratory status, (D) feeding guild, (E) location guild, and (F) synanthropy. Other family = Columbidae $(2.6 \%)$, Paridae $(2.0 \%)$, Corvidae $(1.3 \%)$, Regulidae (1.3\%), Emberizidae (0.7\%), Fringillidae (0.7\%), and Sittidae $(0.7 \%)$. Other location $=$ ground to undergrowth gleaner $(5.3 \%)$, bark excavator (4.6\%), air hawker under canopy $(3.3 \%)$, ground forager $(1.3 \%)$, and lower to upper canopy gleaner $(0.7 \%)$.
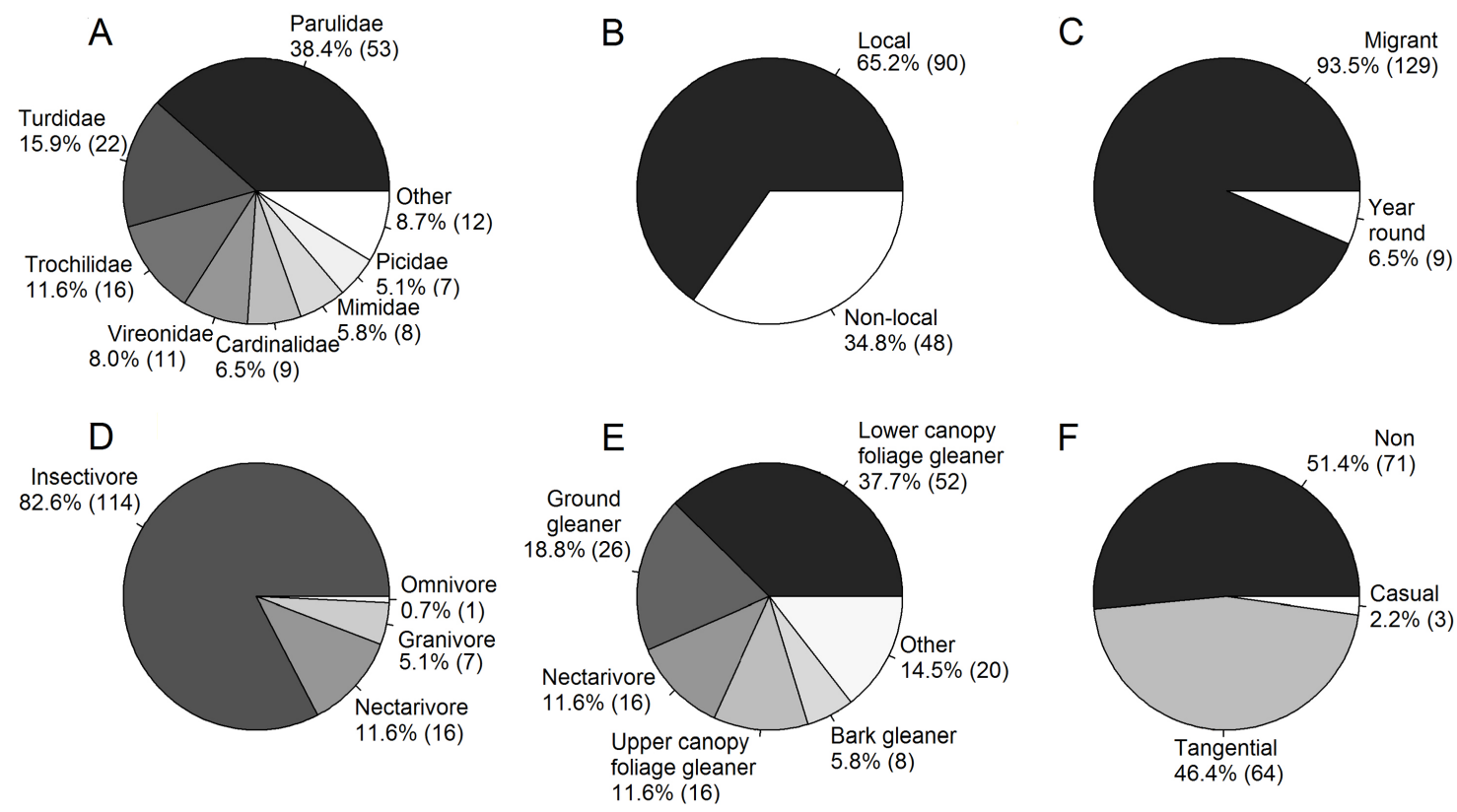

\section{Taxonomy and collision susceptibility}

Of the 40 species we recorded during the campus point count survey, 36 had a collision total on or within their confidence intervals (CI), meaning their number of collisions could not be differentiated from chance. However, many of these results (31) occurred simply because the species was never observed during the collision survey and their background abundance was too low to lift their lower CI above zero. Additionally, 11 species collided with windows, but were not seen or heard during point counts.

Despite these limitations, the CI results provided cases of noteworthy deviation from expected number of collisions (Fig. 3A). Three species, American Goldfinch (Spinus tristis), Ovenbird (Seiurus aurocapilla), and Red-eyed Vireo (Vireo olivaceus), collided more than their abundance-based collision estimates, indicating susceptibility to collisions. Conversely, one species, the House Finch, showed a lower than expected number of collisions.

Scaling up to taxonomic family, Parulidae and Vireonidae had collision numbers above their CI, representing a level of susceptibility that could not be attributed to chance (Fig. 3B). However, Vireonidae vulnerability simply reflected the susceptibility of one species, the Red-eyed Vireo. Paridae offered a contrasting case of collision, an observed collision number below the CI. Additionally, the Mimidae had collision numbers equal to their lower CI, but the family was prevalent enough that this lower value was not equal to zero. Of the 21 families observed during point counts, 11 were not detected as collision victims and had a lower CI of zero. Only two families, Trochilidae and Regulidae, were recorded in the collision survey, but not in the point count survey. Six families collided more than zero, but remained within their confidence intervals, i.e., collided at rates expected based on abundance, including Cardinalidae, Turdidae, and Picidae. All taxonomic orders occurred within their confidence intervals.

\section{Breeding and migration status}

Although they accounted for a substantial proportion of collisions at Duke in 2015 (81\%), species with populations that breed locally still collided less often than expected when factoring in their local abundance. This result is in contrast to nonlocally breeding species that collided more than expected based on background prevalence (Fig. 4A). A similar, though more pronounced pattern emerged between resident and migratory species. Year round residents' collision numbers were well below the CI and migrants' well above (Fig. 4B). Migratory species were disproportionally vulnerable to collisions, regardless of their abundance.

\section{Feeding strategies}

Grouping based on feeding guild indicated that omnivores, which with the exception of one Blue Jay (Cyanocitta cristata), were entirely absent from carcass surveys, were abundant enough to be considered less susceptible to colliding with windows (Fig. 4C). In the location classification, the ground to undergrowth gleaners had lower than expected collision numbers (Fig. 4D), despite relatively high observed numbers of collisions. Conversely, multiple types of lower to upper canopy foliage gleaners collided at rates higher than the $95 \% \mathrm{CI}$. 
Fig. 3. Confidence intervals (bars) and observed rates (dots) for (A) 9 species. The following species were omitted with a lower confidence interval equal to zero and no collisions during the Spring and Fall 2015 Duke collision surveys: AMCR, BAWW, BHCO, BHNU, BLJA, BLWB, BTNW, CACH, CARW, DOWO, EATO, EUST, GBHE, GRCA, HAWO, HETH, NOFL, NOMO, NRSW, PBGR, PIWA, RBWO, ROPI, RTHA, SCTA, SPSA, TUTI, UYRW, WBNU, WOTH, and WTSP (see Table 2 for AOU codes). (B) 21 families observed during campus point count survey.
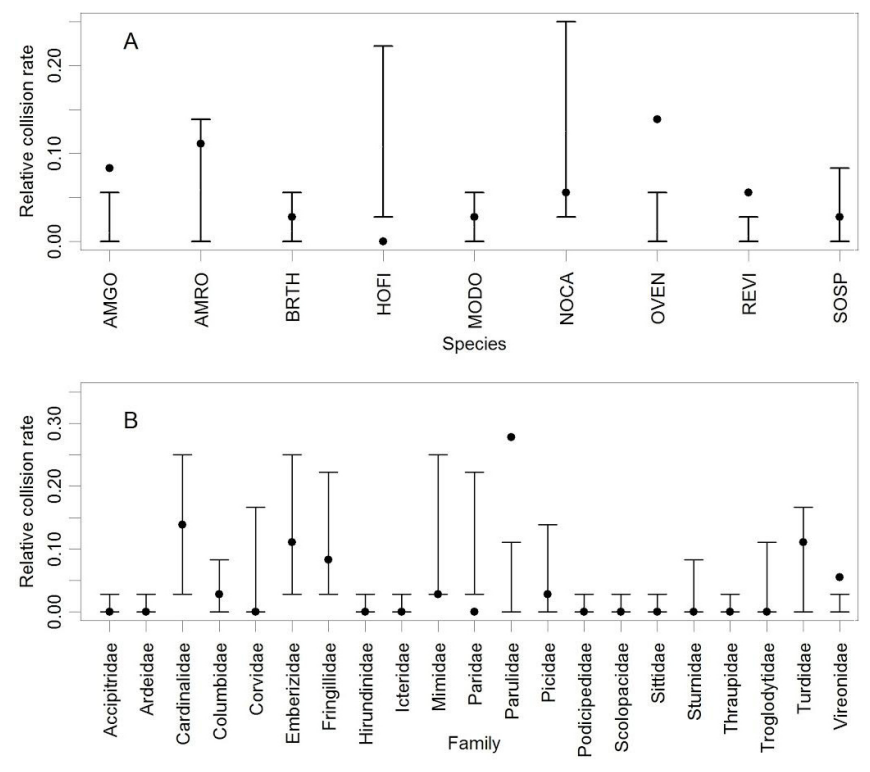

\section{Synanthropy}

Our ordinal measure of positive human association did not give any clear indication of susceptibility or immunity. Casual, tangential, and nonsynanthropes' collision numbers all reflected their prevalence on Duke's Main Campus. Full synanthropes were not observed in the carcass survey and were not prevalent enough to lift their lower CI above zero (Fig. 4E).

\section{DISCUSSION}

The findings of the Duke Case Study provide evidence counter to the hypothesis that collision numbers across species and other categories were simply a reflection of relative abundances, corroborating the results of other recent studies (Kahle et al 2016, Sabo et al. 2016). We witnessed several instances where locally abundant birds rarely collided and opposite cases where locally scarce birds frequently collided. Therefore, we conclude that there are significant differences in a species' susceptibility to collide against or avoid windows. These qualities emerged at nearly every level of classification: species, family, breeding status, migratory status, feeding guild, and feeding location. The recurrence of vulnerability and resistance indicates the complex nature of collisions; they are not reducible to a single behavior or trait, but are related to diverse and likely interacting factors.
Fig. 4. (A) Comparison of expected and observed collision rates for local and nonlocal breeders, as defined by Cook (2008). (B) Similar comparison for migratory status derived from weekly checklist (Cook 2008). (C) Confidence interval comparison based on González-Salazar et al.'s guild classification (2014). Nectarivores were absent from this comparison despite making up 14\% $(n=5)$ of collisions at Duke in spring and fall 2015 because they were not observed during the campus point survey. (D) Finer guild comparison using González-Salazar et al.'s subclassification related to feeding location (2014). Guilds were loosely sorted left to right on foraging height. (E) Comparison of simulated versus observed collision rates among Johnston's (2001) synanthropic classes.
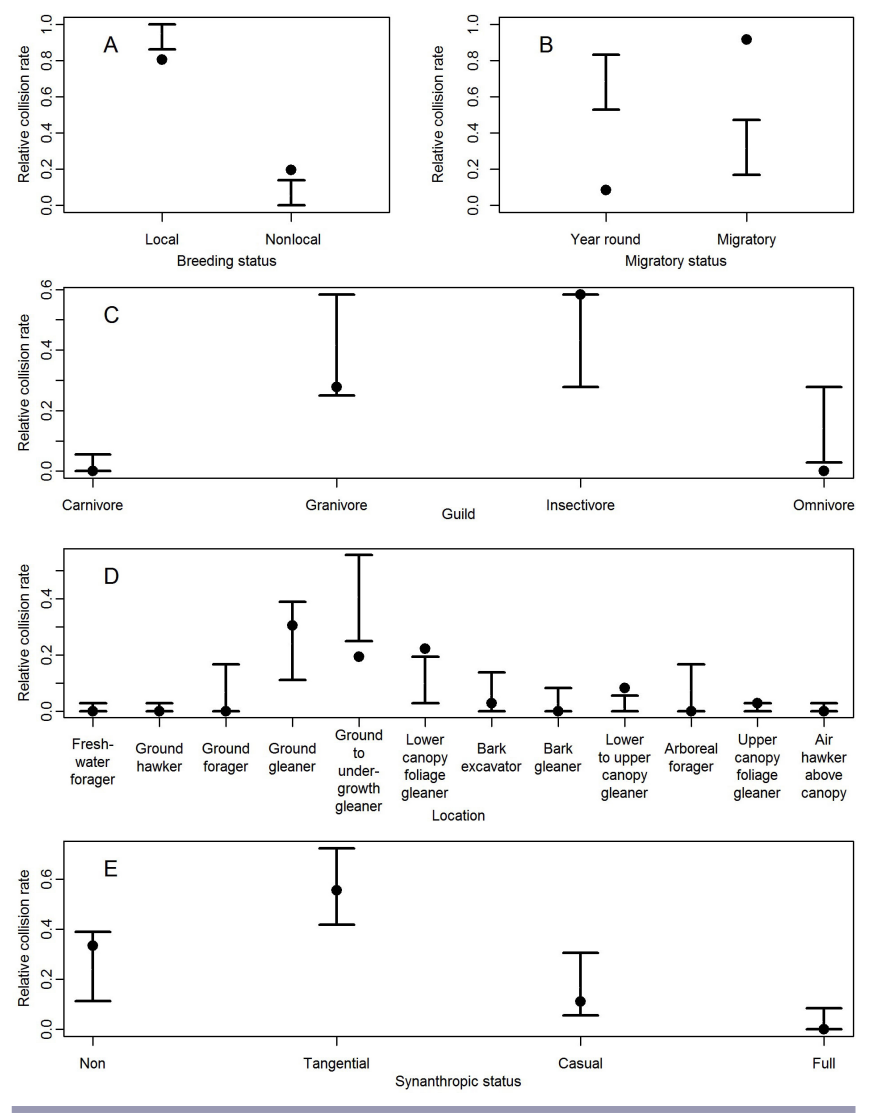

There were also many instances in our analyses of individual bird groups where we could not find evidence to suggest that the observed number of collisions was driven by factors other than chance and abundance. These cases neither disprove the general role of species traits nor prove an entirely random nature to window collisions. Instead, these findings underscore the importance of considering local species prevalence. Kahle et al. (2016) and Sabo et al. (2016) found many similar instances where number of collisions was not discernable from chance and abundance. This observation has major implications for how collision tallies are considered and any subsequent understanding of collision vulnerability. Factoring in local abundance provides 
greater appreciation for the inherent uncertainty behind collision frequency data in terms of species-specific vulnerability.

Within the context of our case study, there were multiple occasions where collision frequencies alone did not give enough information about the collision patterns of a species. For example, the Northern Cardinal, which accounted for $6 \%$ of collisions and has often been reported as a frequent victim (Dunn 1993, Blem and Willis 1998, Hager et al. 2008), was actually within the expected range of collision numbers. Sabo et al. (2016) reported this same species colliding less often than expected based on their mist netting captures. Complementing the standard carcass survey method, we found that the vulnerability of ground to undergrowth gleaners is better informed by putting number of collisions in the context of relative local abundance. Although this group had the third highest number of collisions, it was also so abundant around Duke's Main Campus that its collision numbers were lower than expected, indicating a tendency to avoid collisions.

Although differences in spatial extent, timing, and survey effort limited how much direct comparison we could make between the Triangle Study and Duke Case Study, we did find two major discrepancies in results worth noting. In the Triangle Study, locally breeding species appeared to collide disproportionately with buildings. However, the Duke Case Study showed this same group actually collided less often than expected. Additionally, the near absence of full synanthropes on Duke University's Main Campus suggested the Triangle Study's lack of full synanthrope casualties was not due to any acclimation to urban settings, but to a general scarcity of these birds.

In addition to illustrating the importance of putting bird collision data in the context of local species abundance, our results also indicate categories of birds that appear to be especially vulnerable to window collisions. For example, the finer guild classification analysis suggests that the vertical location of foraging affects the vulnerability of birds. Although leaf gleaners exhibited notably high numbers of collision relative to their abundances, groundbased feeders fared as well as chance would predict or better. Species adapted to foraging under the canopy, like foliage gleaners, fly through small spaces in the thick, forested understory. This behavior may increase their vulnerability to window collisions as they potentially confuse windows for understory openings or are simply unable to cope with the unfamiliar obstacles of urban settings.

Additionally, the more transitory groups of birds, migrants and nonlocal breeders, showed considerable susceptibility to window collisions in the case study. This finding on migratory status is also supported by several previous studies (Arnold and Zink 2011, Loss et al. 2014), including those that accounted for the local abundances (Kahle et al. 2016, Sabo et al. 2016). These relatively high numbers of collisions may be due to unfamiliarity with the local landscape and human structures, though investigation into the causality underlying these relationships is beyond the scope of this study. We consider the vulnerability of migrants to be of particular concern because this group contains many species that already face a large number of threats such as land development, invasive species, and climate change (Kirby et al. 2008).

\section{Limitations of analysis}

There were several limitations to our survey of campus birds that may have affected our confidence interval analysis. First, we assumed that we surveyed at the correct spatial scale to capture an accurate impression of the potential pool of collision victims. However, it is possible that birds outside our sampling frame, from neighboring Duke Forest for example, may have shared some of the risk of collision with our six surveyed buildings. It is also possible that abundance at a finer spatial scale could be important for collisions, for example birds may be susceptible to collisions because they are attracted to ornamental vegetation surrounding buildings. Second, we observed high levels of ambient noise at several survey points. It was difficult in these cases to disentangle the effect of ambient noise as a distraction to observation and a deterrent to birds. Third, and possibly most significantly, we did not count flyovers during our surveys. This technique almost certainly led to an underestimation of species that forage on the wing such as hummingbirds, swallows, and hawks. Fourth, we were not able to carry out scavenging experiments, so our carcass surveys might be underestimating the number of collisions. Overall, our analyses are not able to estimate the relative impact of collisions on species' populations; our results are a hint of which species might be most affected, but we recommend detailed population studies for better risk assessments.

Another phenomenon in the data suggests further limitations. Ten out of 18 species observed during spring and fall 2015 carcass surveys at Duke were not observed during point counts. This trend could be caused by several factors. These species may be so rare their prevalence is too low for detection with standard point count methods, but their susceptibility to collisions is high enough to reveal their presence in the collision survey. Alternatively, species observed only during the collision survey may be relatively abundant, but secretive, with low detection probabilities. Nonetheless, there was substantial and often complete overlap between the carcass and point count datasets when considered in the context of our other classification methods.

Finally, it is possible that the susceptibility of various bird groups may be related to characteristics of the buildings themselves and/ or the habitats immediately proximate to the buildings. In a previous study assessing relationships between building characteristics and collisions we found that buildings with large surface areas of glass contribute disproportionately to collisions on Duke's campus (Ocampo-Peñuela et al. 2016). We emphasize that the bird groups we find to be susceptible to collisions in this study, are specifically susceptible to the dominant buildings in our study area. Other types of buildings, such as single-family residences, may be more threatening to different types of birds. The presence of feeders at residences has been shown to have a strong influence on collision risk (Kummer et al. 2016), but we observed no feeding stations at any of the study buildings throughout the course of the study.

\section{CONCLUSIONS AND FUTURE DIRECTIONS}

Our research demonstrates that local abundance and species traits together offer a better explanation of collision frequencies than either factor taken alone. We found evidence for susceptibility to window collisions among both taxonomic and functional bird classes, even when accounting for the potentially confounding 
effect of abundance. We hope other researchers will incorporate considerations of functional groups into future analyses of collision vulnerability. Additionally, we recommend conducting bird surveys in parallel with carcass surveys when evaluating collision vulnerability in different groups of birds. Once larger datasets with paired relative abundance and carcass data become available, we suggest researchers analyze the interactions and relative influence of the species traits we have linked to collision.

Point counts may be preferable to other bird survey techniques in this research context. Although mist-net surveys may capture many of those birds traveling at window level (Sabo et al. 2016) and area searches may better reveal secretive species (Kahle et al. 2016), point counts are adaptable, easily implemented, and noninvasive. The flexibility of this survey approach allowed us to adjust easily for construction, local events, and other inconveniences likely to be encountered in future suburban and urban collision studies. Relative to Kahle et al. (2016) and Sabo et al. (2016), point counts allowed us to develop a comparable understanding of the influence of local abundance without the complications of permitting or additional field hours. Ideally, point counts can be widely and easily adopted alongside studies of collision vulnerability.

Taking this approach may help limit the amount of disagreement between studies, creating a more cohesive understanding of collision vulnerability. This effort must also involve a move toward consistent definitions of migratory status and other functional classifications, otherwise future researchers will have difficulty comparing results across studies. We also suggest that future research on window collisions begin to consider the year-to-year variability in collision frequencies. Many studies, ours included, have only captured a "snapshot" of the problem. Long-term datasets are needed to assess the annual variation in collision frequencies. This insight will reveal how reliable one-year studies are for understanding general patterns of collision. Finally, we acknowledge a need for greater understanding of the relevant scales of local abundance, specifically, an empirical definition of the distance at which birds are at legitimate risk of collision with a given building. By addressing these issues and adopting these methodologies, researchers can better understand bird-window collisions and consequently improve and accelerate mitigation efforts.

Responses to this article can be read online at: http://www.ace-eco.org/issues/responses.php/1014

\section{Acknowledgments:}

We would like to thank the many volunteers at all campuses who contributed carcass data to our study. Additional thanks go to Dr. Dean Urban and Dr. John Poulsen for their guidance on technical components of this study.

\section{LITERATURE CITED}

Arnold, T. W., and R. M. Zink. 2011. Collision mortality has no discernable effect on population trends of North American birds. PLoS ONE 6(9):e24708. http://dx.doi.org/10.1371/journal. pone. 0024708

Bibby, C. J., N. D. Burgess, D. A. Hill, and S. H. Mustoe. 2000. Bird census techniques. Academic Press, San Diego, California, USA.

Blem, C. R., and B. A. Willis. 1998. Seasonal variation of humancaused mortality of birds in the Richmond area. Raven 69(1):3-8.

Cook, W. 2008. Chapel Hill Bird Club weekly frequency checklist. Chapel Hill Bird Club, North Carolina, USA.

Dunn, E. H. 1993. Bird mortality from striking residential windows in winter. Journal of Field Ornithology 63(3):302-309.

Environmental Systems Resource Institute (ESRI). 2015. ArcMap 10.3.1. ESRI, Redlands, California, USA.

González-Salazar, C., E. Martínez-Meyer, and G. LópezSantiago. 2014. A hierarchical classification of trophic guilds for North American birds and mammals. Revista Mexicana de Biodiversidad 85(3): 931-941. http://dx.doi.org/10.7550/rmb.38023

Hager, S. B., and B. J. Consentino. 2014. Surveying for bird carcasses resulting from window collisions: a standardized protocol. PeerJ PrePrints 2:e406v1. http://dx.doi.org/10.7287/ peerj.preprints. $406 \mathrm{v} 1$

Hager, S. B., B. J. Consentino, and K. J. McKay. 2012. Scavenging affects persistence of avian carcasses resulting from window collisions in an urban landscape. Journal of Field Ornithology 83 (2):203-211. http://dx.doi.org/10.1111/j.1557-9263.2012.00370.x

Hager, S. B., H. Trudell, K. J. McKay, S. M. Crandall, and L. Mayer. 2008. Bird density and mortality at windows. Wilson Journal of Ornithology 120(3):550-564. http://dx.doi.org/10.1676/07-075.1

Johnston, R. F. 2001. Synanthropic birds of North America. Pages 49-67 in J. M. Mazluff, R. Bowman, and R. Donnelly, editors. Avian ecology and conservation in an urbanizing world. Kluwer Academic, Norwell, Massachusetts, USA. http://dx.doi. org/10.1007/978-1-4615-1531-9_3

Kahle, L. Q., M. E. Flannery, and J. P. Dumbacher. 2016. Birdwindow collisions at a West-Coast urban park museum: analyses of bird biology and window attributes from Golden Gate Park, San Francisco. PLoS ONE 11(1):e0144600. http://dx.doi. org/10.1371/journal.pone.0144600

Kirby, J. S., A. J. Stattersfield, S. H. Butchart, M. I. Evans, R. F. A. Grimmett, V. R. Jones, J. O’Sullivan, G. M. Tucker, and I. Newton. 2008. Key conservation issues for migratory land- and waterbird species on the world's major flyways. Bird Conservation International 18(1):S49-S73. http://dx.doi.org/10.1017/s0959270908000439

Klem, D. Jr. 1989. Bird-window collisions. Wilson Bulletin 101:606-620.

Klem, D. Jr. 1990a. Bird injuries, cause of death, and recuperation from collisions with windows (Heridas, Causas de Muerte y Restablecimiento de Aves que Chocan con Ventanas). Journal of Field Ornithology. 61(1):115-119. 
Klem, D. Jr. 1990b. Collisions between birds and windows: mortality and prevention (Colisiones de pájaros con ventanas: mortalidad y prevención). Journal of Field Ornithology. 61 (1):120-128.

Klem, D. Jr. 2009. Avian mortality at windows: the second largest human source of bird mortality on earth. Pages 244-251 in T. D. Rich, C. Arizmendi, D. Demarests, and C. Thompson, editors. Proceedings of the Fourth International Partners in Flight Conference: tundra to tropics. Partners in Flight, McAllen, Texas, USA.

Klem, D. Jr. 2010. Sheet glass as a principle human associated avian mortality factor. Pages 276-289 in S. K. Majumdar, T. L. Master, M. Brittingham, R. M. Ross, R. Mulvihill, and J. Huffman, editors. Avian ecology and conservation: a Pennsylvania focus with national implications. Pennsylvania Academy of Science, Easton, Pennsylvania, USA.

Kummer, J. A., E. M. Bayne, and C. S. Machtans. 2016. Use of citizen science to identify factors affecting bird-window collision risk at houses. Condor 118(3):624-639. http://dx.doi.org/10.1650/ condor-16-26.1

LeGrande, H., J. Haire, N. Swick, and T. Howard. 2016. Birds of North Carolina: their distribution and abundance. Carolina Bird Club, Raleigh, North Carolina, USA. [online] URL: http:// ncbirds.carolinabirdclub.org/

Longcore, T., and P. A. Smith. 2013. On avian mortality associated with human activities. Avian Conservation and Ecology 8(2):1. http://dx.doi.org/10.5751/ace-00606-080201

Loss, S. R., T. Will, and P. P. Marra. 2015. Direct mortality of birds from anthropogenic causes. Annual Review of Ecology, Evolution, and Systematics 46:99-120. http://dx.doi.org/10.1146/ annurev-ecolsys-112414-054133

Loss, S. R., T. Will, S. S. Loss, and P. P. Marra. 2014. Bird-building collisions in the United States: estimates of annual mortality and species vulnerability. Condor 116(1):8-23. http://dx.doi. org/10.1650/condor-13-090.1

O'Connell, T. J. 2001. Avian window strike mortality at a suburban office park. Raven 72(2):141-149.

Ocampo-Peñuela, N., R. S. Winton, C. J. Wu, E. Zambello, T. W. Wittig, and N. L. Cagle. 2016. Patterns of bird-window collisions inform mitigation on a university campus. PeerJ 4:e1652. http:// dx.doi.org/10.7717/peerj.1652

R Development Core Team. 2015. R: a language and environment for statistical computing, version 3.2.2. $\mathrm{R}$ Foundation for Statistical Computing, Vienna, Austria.

Sabo, A. M., N. D. G. Hagemeyer, A. S. Lahey, and E. L. Walters. 2016. Local avian density influences risk of mortality from window strikes. PeerJ 4:e2170. http://dx.doi.org/10.7717/ peerj. 2170

Schaub, M., M. Kéry, P. Korner, and F. Korner-Nievergelt. 2011. A critique of 'Collision mortality has no discernable effect on population trends of North American Birds.' PLoS One Comment. [online] URL: http://journals.plos.org/plosone/article/ comment?id=info $\% 3$ Adoi $\% 2$ F $10.1371 \% 2$ Fannotation $\% 2$ F 68 b 2 f3baa22b-499c-ae55-4aaf7013e6b1

U.S. Environmental Protection Agency. 2013. EnviroAtlas - Meter Resolution Urban Area Land Cover Map for Durham, NC (2010). In U.S. EPA Office of Research \& Development (ORD) - National Exposure Research Laboratory (NERL), editor. Research Triangle Park, North Carolina, USA.
Editor-in-Chief: Ryan Norris Subject Editor: Erin Bayne
Sponsored by the Society of Canadian Ornithologists and Bird Studies Canada Parrainée par la Société des ornithologistes du Canada et Études d'oiseaux Canada

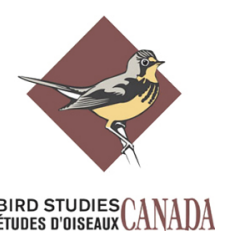

